\title{
The role of family environment in developing the entrepreneurial intention of young Tunisian students
}

\author{
Nejib Ben Moussa, Syrine Kerkeni
}

\section{A B S T R A C T}

Objective: The objective of the article is to identify the role and importance of family environment (parental support for autonomy, entrepreneurial role model, and family support for entrepreneurship) in determining the entrepreneurial intention of young Tunisian students in a post-revolution context.

Research Design \& Methods: The study is based on a quantitative approach using a survey of 297 final year under-graduate students in Tunisian universities. Data analysis was performed using Statistical Package for the Social Sciences (SPSS) V23 software.

Findings: The results show that parental support for autonomy as the promotion of independence and exposure to an entrepreneurial role model are the most important factors capable of stimulating entrepreneurial intention. Contrary to our expectations, we found that the family support for entrepreneurship (financial capital and social capital) has no effect on the entrepreneurial intention of young students.

Implications \& Recommendations: Parents should be aware that orienting their children towards entrepreneurship is first developed at the family level. Their role is therefore essential in encouraging the promotion of independence. Parents should also bring their children closer to family entrepreneurs so as to build on their success.

Contribution \& Value Added: Our main contribution is the development of an empirically verified model that high-lights relationships between different components of family environment and the entrepreneurial intention of final year undergraduate students.

Article type: research article

Keywords: $\quad$ entrepreneurial intention; parental support for autonomy; entrepreneurial role model;

financial support; social support

JEL codes: $\quad$ F23, L26,M16

Received: 1 March $2020 \quad$ Revised: 15 September $2020 \quad$ Accepted: 22 September 2020

\section{Suggested citation:}

Ben Moussa, N., \& Kerkeni, S. (2021). The role of family environment in developing the entrepreneurial intention of young Tunisian students. Entrepreneurial Business and Economics Review, 9(1), 31-45. https://doi.org/10.15678/EBER.2021.090102

\section{INTRODUCTION}

Since 14 January 2011, Tunisia's post-revolution environment has been characterised by political, economic, and social crises (Ben Moussa, 2018). In addition, in 2017 the Tunisian government decided to suspend recruitment in the public sector. Under such austerity measures, young people must move towards launching their own projects to deal with unemployment.

Bearing on the theory of planned behaviour (Ajzen, 1991) and findings from previous research, the study of entrepreneurial intention enriches understanding of entrepreneurial behaviour (González et al., 2019). Indeed, the decision to go into an independent business requires, in the first place, entrepreneurial will (Ajzen, 1991). The latter can be determined when we consider personal and contextual factors (Shapero \& Sokol, 1982). Ajzen (1991) shows that entrepreneurial potential appears in specific contexts that promote attitudes, social norms, and perceptions of behaviour control that result in the manifestation of entrepreneurial intention. 
Thus, the environment in which a person develops can facilitate or inhibit launching a business. It seems that the family environment, as a factor that influences and gears career choices, determines the personality and behaviour of the individual and brings - besides to financial support - a relational network that stimulates entrepreneurial intention. Family environment is the first social experience of students (Boudabbous, 2011). Indeed, family environment denotes the entire fundamental system that transfers entrepreneurial values. It is for this reason that we first bear on the literature examining the effect of family environment on entrepreneurial intention as a factor acting on the perceived desirability and feasibility of entrepreneurial intent (Ajzen, 1991; Shapero \& Sokol, 1982). Several studies show that the family is a determining factor of entrepreneurial intention but few focus on identifying the components of the family concept and on showing their effect on the development of entrepreneurial intention in young people. To our knowledge, few previous studies scrutinised the relationship of the family environment with its different components and entrepreneurial intent.

In our study, we will try to answer the following question: What is the impact of family environment on the entrepreneurial intention of young people? By answering this question, we hope to determine the relative importance of each component of family environment in the development of entrepreneurial intention among young people.

The current study bases on a quantitative approach using a survey of 297 final year undergraduate students at public universities in Tunis. Data analysis was performed using the SPSS V23 software.

Thus, our paper is structured as follows. We first review the relevant literature, then we outline our methodology to test our research hypotheses, and finally, we discuss the main results.

\section{LITERATURE REVIEW}

In this section we first present the two basic concepts of our study. These are entrepreneurial intention and family environment. Then we outline the nature of the relationship between them.

\section{Entrepreneurial Intention}

Since it was identified as the best predictor of entrepreneurial behaviour (Ajzen, 1991), entrepreneurial intention continues to attract entrepreneurship researchers' attention (Leung et al., 2020; Bazan et al., 2020). In fact, any planned behaviour, including starting up a new business venture, cannot take place without the intention of doing business (Ajzen, 1991). Entrepreneurial intention is considered to be the first step in the process of business creation (Ajzen, 1991) reflecting the effort a person is willing to make to actually start a business. Engle et al. (2010) defined entrepreneurial intention as a deliberate desire to go into business. Indeed, it is personal belief that is translated into an ability to assess the feasibility of the idea (Bird, 1992). Therefore, entrepreneurial intention is a thoughtful combination of goal and the means to achieve it. It is also known as a cognitive representation determined by needs, values, motivations, and beliefs (Bird, 1992). As shown by the entrepreneurial event model (Shapero \& Sokol, 1982) and the theory of planned behaviour proposed by Ajzen (1991), Carmen et al. (2016) prove that entrepreneurial intention can be developed throughout a person's life and several factors can influence it. Previous research (e.g. Ajzen, 1991; Shapero \& Sokol, 1982) showed that entrepreneurial intention depends on:

- attitude towards action, which reflects the degree of perceived desirability of behaviour (Shapero \& Sokol, 1982). In other words, it is a favourable or unfavourable assessment of the intended behaviour,

- perceived behavioural control, which refers to the feeling of self-efficacy, i.e. the perceived ability to perform a specific behaviour (Ajzen, 1991). Past experiences, psychological and emotional events are variables that may influence the sense of self-efficacy in an individual,

- social norms reflect the influence of the potential entrepreneur's entourage on their decision to start a business.

Scholars (e.g. Hayton \& Cacciotti, 2014) identify several factors that may influence the entrepreneurial intention, such as personal effectiveness, personality traits, work experience, entrepreneurship education, societal orientation of gender roles, parental behaviour, family history, neighbourhood, school, peer group, and work status. However, in our study, we are only interested in the factor of family environment and its impact on the entrepreneurial intention of young people. Therefore, the 
peculiarity of our study stems from its sole focus on family environment as the determining factor of entrepreneurial intention applied to its importance.

\section{Family Environment}

Family is the first social entity in which individuals learn to integrate and interact (Wiani et al., 2018). In other words, family has a great influence on the social development of individuals, which is where they learn the basic principles necessary for their integration in society. Family shapes their behaviour, their ways of solving problems, and in particular, how they make decisions (Figueiredo \& Dias, 2012). Family is the environment where the identity and personality of individuals are shaped because of direct and early contact with parents, brothers, sisters, and relatives (Wiani et al., 2018).

The family environment essentially consists of parental support for autonomy (e.g. Anil et al., 2014; Sharma, 2014), entrepreneurial role model (e.g. Basow \& Howe, 1980), and family support for entrepreneurship (e.g. Bird \& Weinberg, 2016; Sharma, 2014).

The previous studies have examined the impact of the family environment concept on entrepreneurial intention, as a whole and unidimensional construct. Unlike our study, which is interested in analyzing the impact of its several dimensions on entrepreneurial intention.

\section{Parental Support for Autonomy}

In developmental psychology, the term autonomy was associated with independence, self-determination, and self-assertion (Beyers et al., 2003). In the field of cross-cultural psychology, autonomy is defined as the capacity to act on personal goals and interests, namely the development of individual selfdetermination (Kyriaki et al., 2014). Under the self-determination theory proposed by Deci et al. (1991), parental support for autonomy leads to positive, affective, cognitive, and behavioural consequences which encourage self-expression, self-asserting, and the adoption of more mature behaviours by children. In addition, psychological self-reliance determines parents' ability to stimulate the desire for discovery, but also to encourage children to express one's opinions, desires, and preferences, along with building in them problem-solving skills (Prinzie et al., 2009). Consequently, the concept of parental support for autonomy takes two forms (Soenens et al., 2005). It is initially a question of perceived promoting of independence $(\mathrm{PI})$ through parental educational practices, i.e. parents tend to develop and promote decision-making and freedom of expression in their children (Silk et al., 2003). On the other hand, parental support for autonomy refers to the perceived promotion of volitional functioning (PVF), i.e. parents favour the will of psychological independence (Soenens et al., 2005).

Autonomy is an influential predictor of entrepreneurial intention (Al-Jubari et al., 2017). Research published in the subject shows that parenting practices are the conditions that predispose an individual to have entrepreneurial traits and the intention to set up a business project, through encouragement of creativity, risk taking, promotion of autonomy, and innovative thinking (Anil et al., 2014). Indeed, parents develop the entrepreneurial intention of their children when they promote their independence by giving them more freedom to think and make decisions in the family. In the same way, by stimulating the voluntary functioning of their children, parents develop their entrepreneurial spirit. Therefore, it is likely that parental support for autonomy, through its two components, contributes to the development of children's entrepreneurial intention. Accordingly, we formulate our hypothesis:

H1.1: Parental support for autonomy as the perceived promotion of independence promotes young people's entrepreneurial intention.

H1.2: Parental support for autonomy as the perceived promotion of volitional functioning promotes young people's entrepreneurial intention.

\section{Entrepreneurial Role Models}

Entrepreneurial role models are a particular type of social capital known for their intense networks and ability to provide secure access to different types of resources (Holienka et al., 2013). Given their importance in the development of entrepreneurial intention, we chose to give entrepreneurial role models special attention and treat them separately from the concept of social capital. Gibson (2004) 
postulates that the role model concept is a combination of two aspects: the role aspect and the modelling aspect. The role aspect translates the identification with his model in terms of similar characteristics and behaviours, while the modelling aspect inspires others to imitate one's personality and acquire the desired abilities and skills (Bosma et al., 2011).

The role model typically plays a major role in determining career choices (Shapero \& Sokol, 1982). $\mathrm{S} /$ he is a person who serves as the basis for imitation in terms of professional goals and decisions (Basow \& Howe, 1980). Therefore, an entrepreneurial role model may be defined as a person who inspires others to acquire desired entrepreneurial skills and become entrepreneurs. In fact, entrepreneurial role models are acknowledged as influencers through their behaviours, which serves as a guide for potential entrepreneurs (Gibson, 2004).

Entrepreneurial research confirms the impact of role models on entrepreneurial intention. In the context of entrepreneurial socialisation, successful entrepreneurial examples promote the learning and acquisition of entrepreneurial skills (Karimi et al., 2014).

Entrepreneurial role models and - more specifically - family members not only help to build one's own network, which is a source of inspiration and motivation, but also to have the skills to launch a business (Holienka et al., 2013). Living in a family of entrepreneurs increases entrepreneurial motivation and intention.

A study conducted by Gray (2006), with 201 Moroccan entrepreneurs to identify the determining factors of their choice of entrepreneurial career showed that $70 \%$ of respondents had a role model and followed the example of a parent or relative. Bearing on this, we formulate the following hypothesis:

H2: Exposing young people to an entrepreneurial role model reinforces their entrepreneurial intention.

\section{Family Support for Entrepreneurship}

Family support for entrepreneurship can take several forms: moral (Boudabous, 2011), financial, and social (Bird \& Weinberg, 2016).

We are interested in studying the influence of social and financial family support, since they are the most useful resources to facilitate the decision to start a business (Bird \& Weinberg, 2016). Financial capital is the starting point of any project, which can be transformed into other types of resources required for the execution and development of entrepreneurship (Edelman et al., 2016). However, Bates (1985) considers that financial capital should be associated with human or social capital to ensure a project's sustainability.

Social capital has three dimensions: structural, cognitive, and relational. The structural dimension refers to the general architecture of connections between actors (Nahapiet \& Ghoshal, 1998). The cognitive dimension refers to structuring resources between parts such as representations and interpretations. The relational dimension refers to all assets obtained through these relationships conditioned by trust, norms, expectations, and obligations (Nahapiet \& Ghoshal, 1998).

Family influence on business creation was extensively studied in several studies that examine family businesses (e.g. Rodriguez et al., 2009). Nevertheless, the effect of family support on stimulating entrepreneurial activities among novice entrepreneurs is poorly studied (Edelman et al., 2016).

Indeed, social capital helps to identify opportunities and sustain company performance (Bhagvatula et al., 2010). Recent studies on social capital have shown that all broader relational networks reinforce the choice of an entrepreneurial career and represent both a tool to help set up projects and entrepreneurial objectives (Sharma, 2014).

Several studies tried to determine the role of family's financial capital in helping novices to choose an independent professional career (Rodriguez et al., 2009), which is often identified as the most rapidly sought capital, which can be transferred across generations (Dyer et al., 2014). Indeed, the availability of family's financial capital is the starting point of the project and positively related to the choice of an entrepreneurial career (Rodriguez et al., 2009). Then, we formulate the following hypothesis:

H3.1: The family's social capital reinforces young people's entrepreneurial intention.

H3.2: The availability of family's financial capital increases young people's entrepreneurial intention. 
Our research model (Figure 1) summarises all of our hypotheses.

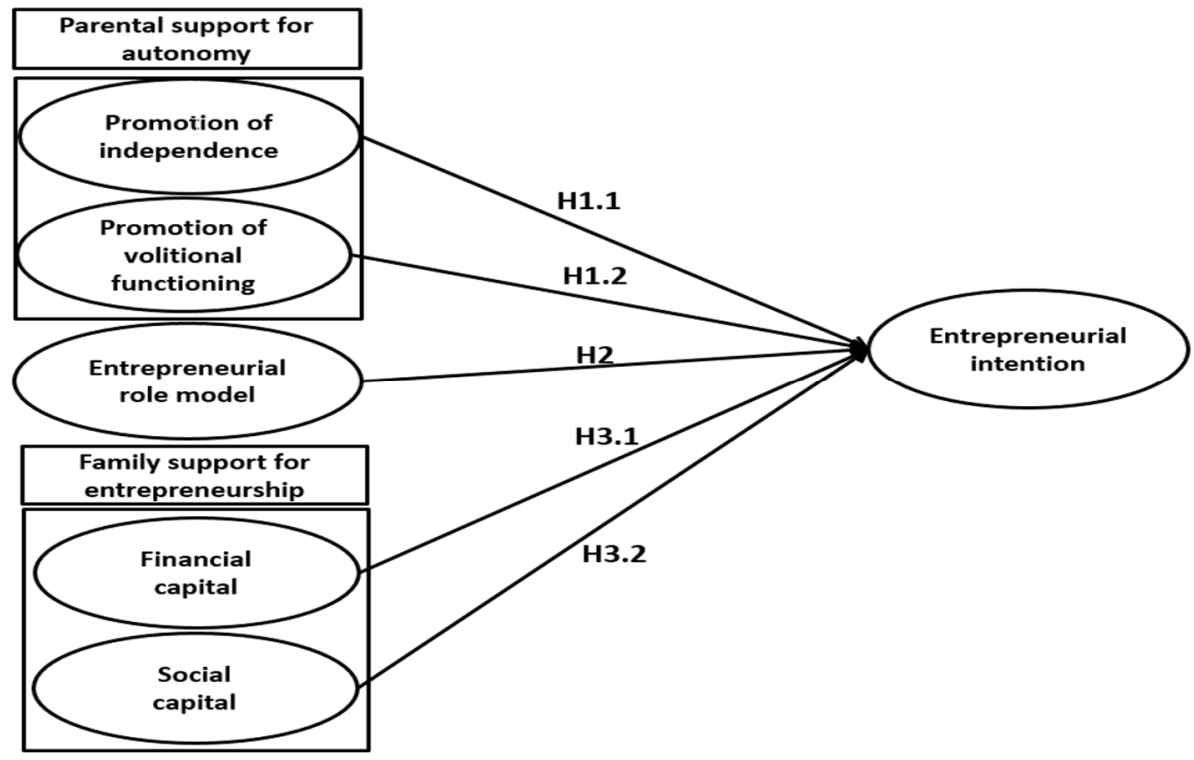

Figure 1. Conceptual model

Source: own elaboration.

\section{RESEARCH METHODOLOGY}

In order to answer and test our research questions and hypotheses, we opted for a questionnairebased survey to gather the data needed to study the role of family environment in the development of entrepreneurial intention. The survey was conducted among final year undergraduate students in Tunisian universities. We distributed 400 questionnaires but we were only able to administer 300 . Three of them were not correctly completed. Therefore, our sample includes only 297 questionnaires. We measured "entrepreneurial intention" with six items inspired by Linan and Chen (2009). A sample item was "I am ready to do anything to be an entrepreneur." The "parental support for autonomy" (perceived promotion of independence and perceived promotion of volitional functioning) has been operationalised by 17 items (Appendix A) adopted from Silk et al. (2003), Grolnick et al. (1991), and Soenens et al. (2007). Sample items were "My mother/father pushes me to think independently," "My mother/father allows me to decide things for myself."

For "entrepreneurial intention "and "parental support for autonomy," we used a five-point Likert scale ranging from strongly agree (1) to strongly disagree (5). The independent variable "entrepreneurial role model" was measured by 12 items inspired by Howard et al. (2006) and rated on a five-point Likert scale ranging from very often (1) to never (5).

Table 1. Demographic characteristics of respondents

\begin{tabular}{|l|c|c|}
\hline \multicolumn{1}{|c|}{ Characteristics } & Frequency & Percent (\%) \\
\hline Sex: & & 63.3 \\
Female & 188 & 36.7 \\
Male & 109 & 100 \\
Total & 297 & \\
\hline Fields of study: & & 41.75 \\
Engineering & 124 & 58.25 \\
Social Sciences & 173 & 100 \\
Total & 297 & \\
\hline
\end{tabular}

Source: own elaboration of the survey $(n=297)$.

The sample item was, "Do you have a self-employed parent or family member who you want to imitate and who has significant discussions with you about their job or business?" "Family support for 
entrepreneurship" (financial capital and social capital) was evaluated by 11 items inspired by Sieger et al. (2011) and used by Lima et al. (2014). Sample items included in this scale were "If I want to start a business my family will provide me with own capital" and "If I want to start a business my family puts me in contact with business networks, partners, and/or potential customers." This variable was also measured by a five-point Likert scale ranging from very sure (1) to not sure at all (5).

\section{RESULTS AND DISCUSSION}

\section{Findings}

Data analysis was performed using the SPSS V23 software. Table 1 presents some characteristics of our sample. As we can see, $63.3 \%$ of young respondents were females, whereas only $36.7 \%$ were males. The sample of our study consists mainly of young Tunisian final year undergraduate students belonging to 25 universities, but we have grouped them in two disciplines (engineering and social sciences). As a result, the majority of the sample (58.25\%) consists of young students in universities that pursuing studies in social sciences (Business administration, Economics and Law), while the rest of the sample $(41.75 \%)$ pursue engineering.

Table 2 presents descriptive statistics of the different variables used in our study. These results show that young people are ready to make all the necessary efforts to create their own projects. But they are not completely prepared to immediately embark on this adventure. Such attitude of young people can be explained by the uncertainty of the post-revolution environment that Tunisia has experienced since 2011.

As for the variable "parental support for autonomy" (the perceived promotion of independence and of volitional functioning), the interviewed young people agree with almost all the statements. Such a trend can be explained by the presence of a democratic parental style, which promotes autonomy.

Respondents report the existence of a very low presence of role model in their family environment. For family support of entrepreneurship, the results show that the different resources - financial and social - necessary for the creation of a business are very unlikely to be provided by the respondents' family environment.

Before studying the relationships between the different constructs of our model, we checked the consistency of their measurement scales. For this reason, we began with reliability analysis, then we performed factor analysis, and finished with multiple linear regression analysis.

We checked the reliability of different concepts of our model with Cronbach's alpha. Table 3 shows that the alpha coefficient of all constructs varies between 0.694 and 0.945 . This proves the adequate internal consistency of all the studied constructs.

Then, we conducted principal component analysis (PCA) in order to purify measurement scales. Let us note that we retained only the items that have the correlation coefficient greater than 0.3 , as recommended by Netemeyer et al. (2003). However, we removed five items (PI1, PI2, PI3, PI4, and PI7) from "parental support for autonomy" due to their low correlation coefficients: two of its items (PVF4 and PVF7) as promotion of volitional functioning and the promotion of independence construct. Similarly, we removed CS8 from the "family support for entrepreneurship" construct for the same reason. A factor analysis was carried out on the dependent variable "entrepreneurial intention." It showed that the construct was unidimensional $(\mathrm{KMO}=0.916$, Bartlett's test $=0.000)$, giving off a factor that expressed $74.871 \%$ of total variance. The factor analysis performed on the first independent variable "parental support for autonomy as promotion of independence" expressed 53.049\% of total variance $(\mathrm{KMO}=0.719$, Bartlett's test $=0.000)$. The second one, "parental support for autonomy as promotion of volitional functioning" (KMO $=0.825$, Bartlett's test $=0.000$ ), expressed $47.218 \%$ of total variance. In the same way, the factor analysis conducted on the independent variable "entrepreneurial role model" showed that it was unidimensional $(\mathrm{KMO}=0.938$, Bartlett's test $=0.000)$, producing a factor that expressed $62.882 \%$ of total variance.

Finally, the factor analysis of the independent variable "family support for entrepreneurship as financial capital" showed that (KMO $=0.691$, Bartlett's test $=0.000$ ) and expressed $67.528 \%$ of total variance. The 
second one, "Family support for entrepreneurship as social capital" ( $\mathrm{KMO}=0.874$, Bartlett's test $=0.000$ ), expressed $69.736 \%$ of total variance. These results prove that the validity is adequate.

Table 2. Descriptive statistics

\begin{tabular}{|c|c|c|c|c|c|c|}
\hline \multicolumn{3}{|c|}{ Items } & Min & Max & Mean & S.D. \\
\hline \multirow{6}{*}{\multicolumn{2}{|c|}{ Entrepreneurial intention }} & El1 & 1 & 5 & 2.32 & 1.253 \\
\hline & & El2 & 1 & 5 & 2.32 & 1.361 \\
\hline & & EI3 & 1 & 5 & 2.02 & 1.310 \\
\hline & & EI4 & 1 & 5 & 2.28 & 1.257 \\
\hline & & EI5 & 1 & 5 & 2.32 & 1.329 \\
\hline & & EI6 & 1 & 5 & 2.25 & 1.239 \\
\hline \multirow{17}{*}{$\begin{array}{l}\text { Parental support for } \\
\text { autonomy }\end{array}$} & \multirow{9}{*}{$\begin{array}{l}\text { Promotion of independ- } \\
\text { ence }\end{array}$} & PI1 & 1 & 5 & 2.21 & 1.209 \\
\hline & & PI 2 & 1 & 5 & 2.53 & 1.366 \\
\hline & & PI 3 & 1 & 5 & 1.74 & 0.989 \\
\hline & & $\mathrm{PI} 4$ & 1 & 5 & 2.03 & 1.242 \\
\hline & & PI 5 & 1 & 5 & 2.10 & 1.233 \\
\hline & & PI 6 & 1 & 5 & 1.70 & 0.963 \\
\hline & & $\mathrm{PI} 7$ & 1 & 5 & 2.13 & 1.163 \\
\hline & & $\mathrm{PI} 8$ & 1 & 5 & 1.76 & 1.056 \\
\hline & & PI 9 & 1 & 5 & 1.83 & 1.062 \\
\hline & \multirow{8}{*}{$\begin{array}{l}\text { Promotion of volitional } \\
\text { functioning }\end{array}$} & PVF1 & 1 & 5 & 1.62 & 0.889 \\
\hline & & PVF2 & 1 & 5 & 1.72 & 0.904 \\
\hline & & PVF3 & 1 & 5 & 2.05 & 0.968 \\
\hline & & PVF4 & 1 & 5 & 3.02 & 1.301 \\
\hline & & PVF5 & 1 & 5 & 1.90 & 0.955 \\
\hline & & PVF6 & 1 & 5 & 1.76 & 0.913 \\
\hline & & PVF7 & 1 & 5 & 3.33 & 1.352 \\
\hline & & PVF8 & 1 & 5 & 1.70 & 0.883 \\
\hline \multirow{12}{*}{\multicolumn{2}{|c|}{ Entrepreneurial role model }} & ERM1 & 1 & 5 & 3.65 & 1.598 \\
\hline & & ERM2 & 1 & 5 & 4.14 & 1.407 \\
\hline & & ERM3 & 1 & 5 & 4.21 & 1.363 \\
\hline & & ERM4 & 1 & 5 & 3.90 & 1.560 \\
\hline & & ERM5 & 1 & 5 & 3.92 & 1.544 \\
\hline & & ERM6 & 1 & 5 & 4.00 & 1.460 \\
\hline & & ERM7 & 1 & 5 & 3.97 & 1.521 \\
\hline & & ERM8 & 1 & 5 & 3.90 & 1.542 \\
\hline & & ERM9 & 1 & 5 & 3.99 & 1.511 \\
\hline & & ERM10 & 1 & 5 & 4.34 & 1.316 \\
\hline & & ERM11 & 1 & 5 & 4.49 & 1.142 \\
\hline & & ERM12 & 1 & 5 & 4.33 & 1.262 \\
\hline \multirow{11}{*}{$\begin{array}{l}\text { Family support for } \\
\text { entrepreneurship }\end{array}$} & \multirow{3}{*}{ Financial capital } & FC1 & 1 & 5 & 3.27 & 1.440 \\
\hline & & FC1 & 1 & 5 & 2.92 & 1.310 \\
\hline & & FC1 & 1 & 5 & 3.23 & 1.405 \\
\hline & \multirow{8}{*}{ Social capital } & SC1 & 1 & 5 & 2.40 & 1.345 \\
\hline & & $\mathrm{SC2}$ & 1 & 5 & 2.60 & 1.340 \\
\hline & & SC3 & 1 & 5 & 2.64 & 1.393 \\
\hline & & SC4 & 1 & 5 & 2.73 & 1.332 \\
\hline & & SC5 & 1 & 5 & 2.51 & 1.363 \\
\hline & & SC6 & 1 & 5 & 2.61 & 1.279 \\
\hline & & SC7 & 1 & 5 & 3.02 & 1.314 \\
\hline & & SC8 & 1 & 5 & 2.59 & 1.375 \\
\hline
\end{tabular}

Note: S.D. - standard deviation.

Source: own elaboration of the survey $(n=297)$. 
Since all the variables in our model are quantitative, we chose the multiple linear regression analyses to test our hypotheses. Before performing multiple linear regression, we first checked that correlation between independent variables showed no multicollinearity problem. In the same way, regression assumptions have been checked to show that there is no violation of these conditions (linearity, the constant variance of error terms, the independence of error terms, and the normal distribution of error terms). Table 5 showed that the variance inflation factor (VIF) was less than 3.3 as suggested by Hair et al. (2011).

Table 3. Results of principal component analysis

\begin{tabular}{|c|c|c|c|c|c|c|}
\hline \multicolumn{2}{|c|}{ Construct } & Item & $\begin{array}{l}\text { Factors } \\
\text { Loading }\end{array}$ & $\alpha$ & KMO & $\begin{array}{l}\text { Variance ex- } \\
\text { plained (\%) }\end{array}$ \\
\hline \multirow{6}{*}{\multicolumn{2}{|c|}{ Entrepreneurial intention }} & El1 & 0.824 & \multirow{6}{*}{0.932} & \multirow{6}{*}{0.916} & \multirow{6}{*}{74.871} \\
\hline & & EI2 & 0.844 & & & \\
\hline & & $\mathrm{EI3}$ & 0.875 & & & \\
\hline & & El4 & 0.887 & & & \\
\hline & & EI5 & 0.877 & & & \\
\hline & & EI6 & 0.884 & & & \\
\hline \multirow{10}{*}{$\begin{array}{l}\text { Parental support } \\
\text { for autonomy }\end{array}$} & \multirow{4}{*}{$\begin{array}{l}\text { Promotion of independ- } \\
\text { ence }\end{array}$} & PI 5 & 0.734 & \multirow{4}{*}{0.694} & \multirow{4}{*}{0.719} & \multirow{4}{*}{53.049} \\
\hline & & PI 6 & 0.830 & & & \\
\hline & & PI 8 & 0.641 & & & \\
\hline & & PI 9 & 0.696 & & & \\
\hline & \multirow{6}{*}{$\begin{array}{l}\text { Promotion of volitional } \\
\text { functioning }\end{array}$} & PVF 1 & 0.668 & \multirow{6}{*}{0.772} & \multirow{6}{*}{0.825} & \multirow{6}{*}{47.218} \\
\hline & & PVF 2 & 0.765 & & & \\
\hline & & PVF 3 & 0.624 & & & \\
\hline & & PVF 5 & 0.610 & & & \\
\hline & & PVF 6 & 0.722 & & & \\
\hline & & PVF8 & 0.721 & & & \\
\hline \multirow{12}{*}{\multicolumn{2}{|c|}{ Entrepreneurial role model }} & ERM1 & 0.849 & \multirow{12}{*}{0.945} & \multirow{12}{*}{0.938} & \multirow{12}{*}{62.882} \\
\hline & & ERM2 & 0.858 & & & \\
\hline & & ERM3 & 0.827 & & & \\
\hline & & ERM4 & 0.878 & & & \\
\hline & & ERM5 & 0.838 & & & \\
\hline & & ERM6 & 0.817 & & & \\
\hline & & ERM7 & 0.644 & & & \\
\hline & & ERM8 & 0.814 & & & \\
\hline & & ERM9 & 0.808 & & & \\
\hline & & ERM10 & 0.715 & & & \\
\hline & & ERM11 & 0.718 & & & \\
\hline & & ERM12 & 0.712 & & & \\
\hline \multirow{10}{*}{$\begin{array}{l}\text { Family support for } \\
\text { entrepreneurship }\end{array}$} & \multirow{3}{*}{ Financial capital } & CF1 & 0.812 & \multirow{3}{*}{0.758} & \multirow{3}{*}{0.691} & \multirow{3}{*}{67.528} \\
\hline & & CF2 & 0.843 & & & \\
\hline & & CF3 & 0.809 & & & \\
\hline & \multirow{7}{*}{ Social capital } & CS1 & 0.838 & \multirow{7}{*}{0.927} & \multirow{7}{*}{0.874} & \\
\hline & & $\mathrm{CS} 2$ & 0.857 & & & \\
\hline & & CS3 & 0.852 & & & \\
\hline & & CS4 & 0.877 & & & 69.736 \\
\hline & & CS5 & 0.797 & & & \\
\hline & & CS6 & 0.794 & & & \\
\hline & & CS7 & 0.827 & & & \\
\hline
\end{tabular}

Note: KMO - Kaiser-Meyer-Olkin. All Bartlett's sphericity tests are equal to 0.000 .

Source: own elaboration of the survey $(n=297)$.

In fact, Model 1 resulted from the multiple linear regression establishing the relationship between entrepreneurial intention (dependent variable) and the five components of family environment (independent variables). 
This model showed (Table 4) that family environment contributes $11.3 \%$ to the formation of entrepreneurial intention (Adj. $R^{2}=0.113$, sig $=0.000$ ). These results are quite satisfactory since entrepre-neurial intention was affected not only by the family environment - the object of our study - but also by other factors mentioned in the literature. The results in Table 5 underline the importance of the contribution of each component of the family environment in the explanation of entrepreneurial intention.

Table 4. Summarised model and statistics of regression

\begin{tabular}{|c|c|c|c|c|}
\hline Model & R square & Adjusted R square & F & Sig. \\
\hline 1 & 0.128 & 0.113 & 8.570 & 0.000 \\
\hline
\end{tabular}

Note: Dependent variable: Entrepreneurial intention; Independent variables: Promotion of independence; Promotion of volitional functioning; Entrepreneurial role model; Financial capital; Social capital.

Source: own elaboration of the survey $(n=297)$.

Indeed, the relationship between parental autonomy support as the promotion of independence and entrepreneurial intention is significant and positive $(\beta=0.193, p=0.006)$. Hence, hypothesis $\mathrm{H} 1.1$ is confirmed.

The relationship between parental autonomy support as the promotion of volitional functioning and entrepreneurial intention is not significant $(\beta=0.032, p=0.643)$. Hence, hypothesis $\mathrm{H} 1.2$ is not confirmed.

Table 5. Regressions coefficients

\begin{tabular}{|c|c|c|c|c|c|}
\hline Hypothesis & $\beta$ & t-value & $p$-value & VIF & Decision \\
\hline H1.1: PI -> El & 0.193 & 2.778 & 0.006 & 1.610 & Supported \\
\hline H1.2: PVF -> El & 0.032 & 0.464 & 0.643 & 1.601 & Unsupported \\
\hline H2: ERM -> El & 0.235 & 4.073 & 0.000 & 1.115 & Supported \\
\hline H3.1: FC -> El & 0.023 & 0.377 & 0.706 & 1.238 & Unsupported \\
\hline H3.2: SC -> El & 0.050 & 0.784 & 0.434 & 1.339 & Unsupported \\
\hline
\end{tabular}

Note: El: entrepreneurial intention; PI: Promotion of independence; PVF: Promotion of volitional functioning; ERM: Entrepreneurial role model; FC: Financial capital; SC: Social capital; VIF: variance inflation factor.

Source: own elaboration of the survey $(n=297)$.

Likewise, the relationship between the entrepreneurial role model variable and entrepreneurial intention is significant and positive $(\beta=0.235, p=0.000)$. This allows us to confirm hypothesis $\mathrm{H} 2$. Finally, the relationship between the two components of family support for entrepreneurship (financial capital and social capital) with entrepreneurial intention is not significant $(\beta=0.023, p=0.706 ; \beta=0.050, p=0.434)$. Hence $\mathrm{H} 3.1$ and $\mathrm{H} 3.2$ are rejected.

\section{Discussion}

The aim of our study was to identify the role and importance of family environment in determining the entrepreneurial intention of young Tunisian students. We have been able to highlight that family has a multifaceted influence on the desire among young students to set up a project (Boudabous, 2011). In fact, entrepreneurial intention is affected by three components of family environment, namely parental support for autonomy (the promotion of independence and of volitional functioning), entrepreneurial role model, and family support for entrepreneurship (financial capital and social capital).

The results of our survey of 297 students showed that parental support for autonomy (the promotion of independence) is an important factor able to stimulate entrepreneurial intention. Similar to Eva's (2004) study of 320 German students, the results showed that an authoritative parenting style leads to the birth of entrepreneurial skills and the development of interest in entrepreneurship. However, our results run counter to those found by Ahmad et al. (2015) who showed that parents have no effect on the entrepreneurial intention of Indonesian students.

Next, we have shown that even low exposure to an entrepreneurial role model is crucial in choosing an entrepreneurial career. Our results are similar to those of many researchers in different contexts (e.g. Howard et al., 2006; Bosma et al., 2011). Hartsenko and Kuttim (2019) have conducted a comparative study of the impact of components planned behaviour theory on entrepreneurial intention between 
Central and Eastern Europe (CEE) and developed European countries. They confirmed that social norms and, in particular, belonging to a family with a business background are likely to stimulate the entrepreneurial intention of young Central and Eastern Europe countries (CEEC) university graduates.

Furthermore, we can confirm that business discussions, work integration, and the different interaction opportunities with the entrepreneurial role model have a positive effect on the entrepreneurial intention in our sample.

Finally, contrary to our expectations, we found that family support for entrepreneurship - expressed in terms of financial capital and social capital of the family - has no impact on the development of young peoples' entrepreneurial intention. Families are unable to provide their children with the social and financial support necessary to start their projects. These results confirm those of Boudabbous (2011) who found that financial constraints have no effect on the development of young Tunisians' entrepreneurial intention.

Moreover, Sharma (2014) studied Indian students to determine whether the impact of different types of capital provided by the family stimulates entrepreneurial career choices - only to find no effect of the a family's financial capital on entrepreneurial intention in his sample. Indeed, Bradley et al. (2011) consider that the availability of family financial resources can lead to a sense of satisfaction and complacency that can restrict the entrepreneurial behaviour of individuals in terms of strategic orientation and entrepreneurial culture.

Let us note that - to our knowledge - studies conducted in countries close to Tunisia, such as Morocco, Egypt, and Algeria have only dealt with the question of the effect of social norms, including the family environment, on entrepreneurial intention.

In Egypt, Engle et al. (2010) found that social norms are an important determinant of the entrepreneurial intention of university students.

In Moroccan context, Gray (2006) showed that $70 \%$ of the respondents had a role model and followed the example of a parent or a relative.

Contrary to what was proven in the Moroccan and Egyptian contexts, no effect of components that constitute planned behaviour theory were revealed among Algerian students. In other words, social norms have no impact on the entrepreneurial intention of Algerian students (St-Jean et al., 2014). Therefore, we may conclude that the effect of social norms varies in North African countries.

Moreover, these results reinforce the idea that the impact of components of The Theory of Planned Behaviour varies from one country to another, and it does not have the same effect in all contexts (Ajzen, 1991).

\section{CONCLUSIONS}

It seems that the entrepreneurial intention of young Tunisians is partly determined by their family environment expressed in terms of parental support for autonomy as the promotion of independence and entrepreneurial role model.

Family is more than ever called upon to play the primary role in the development of the entrepreneurial spirit of children by preparing them for the external environment - which becomes increasingly difficult - and encouraging them to orient themselves towards the business world. Therefore, a considerable change must occur in the family environment in order to prepare young people to create and succeed in new projects.

The practical implications of our study are the following:

- Young people should understand that the government in a post-revolutionary economy is no longer able to provide employment for everyone. They should take advantage of opportunities in the private sector and seek to start their own businesses;

- Parents should know that orienting their children towards entrepreneurship is first developed at the family level. Therefore, their role is essential in encouraging the promotion of independence. Parents should also bring their children closer to family entrepreneurs to build on their success;

- The government should gear national education policy towards developing the entrepreneurial spirit of young people. It is up to schools and universities to assume from the family the role to 
enrich the education of children by imbuing young people with entrepreneurial culture. Furthermore, the government is expected to clarify its economic policies so as to create a favourable economic environment for investments. The government should take steps to encourage young people to undertake independent careers.

However, besides these theoretical and empirical contributions, our study has some limitations. Indeed, the first limitation of our study is essentially related to the structure of our sample. In other words, the answers obtained are certainly representative, but they cannot be generalised because they were collected from 297 students belonging to different academic institutions of Tunis region only. As a reminder, our study focused on social constructs of family system and their impact on entrepreneurial intention. This limited our focus to the differences in family educational practices that are determined by the culture and customs specific to each region. Therefore, it is a question of widening the context by integrating other Tunisian regions.

Bearing on our results and the limitations mentioned above, we suggest that future research broadens the context of our study so as to distinguish the specificities of each region and in order to study the impact of the family system on entrepreneurial intention. Moreover, other moderating variables that can reinforce the existing relationship between the family environment and entrepreneurial intention can be included, such as entrepreneurial self-efficacy and motivation for entrepreneurship. Moreover, future research could develop a longitudinal study to outline the transition from intention to entrepreneurial action. Finally, future research should consider investigating whether parenting practices and family support differ between men and women.

\section{REFERENCES}

Ahmad, R., Lizar, A., \& Mangundjaya, W. (2015). The role of parent's influence and self-efficacy on entrepreneurial intention. The Journal of Developing Areas. 49, 417-430.

Ajzen, I. (1991). The theory of planned behavior. Organizational Behavior and Human Decision. Processes, 50(2), 179-211. https://doi.org/10.1016/0749-5978(91)90020-T

Al-Jubari, I., \& Hassan, A., \& Hashim, J. (2017). The role of autonomy as a predictor of entrepreneurial intention among university students in Yemen. International Journal of Entrepreneurship and Small Business, 30, 325340. https://doi.org/10.1504/IJESB.2017.081950

Anil, B., \& Azize, E. (2014). Women entrepreneurs' personality characteristics and parents' parenting style profile in Turkey. Procedia - Social and Behavioral Sciences, 109, 92-97. https://doi.org/10.1016/j.sbspro.2013.12.425

Basow, S., \& Howe, K. (1980). Role-model influence: Effects of sex and sex-role attitude in college students. Psychology of Women Quarterly, 4, 558-572.

Bates, T. (1985). Entrepreneur Human Capital Endowments and Minority Business Viability. Journal of Human Resources, 20(4), 540-554.

Bazan, C., Gaultois, H., \& Shaikh, A. (2020). A systematic literature review of the influence of the university's environment and support system on the precursors of social entrepreneurial intention of students. Journal of Innovation and Entrepreneurship, 9(4), 1-28. https://doi.org/10.1186/s13731-020-0116-9

Ben Moussa, N. (2018). The contribution of job satisfaction, organizational climate and employee commitment on management innovation in Tunisian SMEs: The effect of the post-revolution environment. Economics Bulletin, 38(4), 2167-2183.

Beyers, W., Goossens, L., Vansant I., \& Moors, E. (2003). A structural Model of autonomy in Middle and Late Adolescence: Connectedness, Separation, Detachment and Agency. Journal of Youth and Adolescence, 32(5), 351365. https://doi.org/10.1023/A:1024922031510

Bird, B. (1992), The operation of intentions in time: The emergence of new venture. Entrepreneurship Theory and Practice, 17(1), 11-20. https://doi.org/10.1177/104225879201700102

Bird, M., \& Wennberg, K. (2016). Why family matters: The impact of family resources on immigrant entrepreneurs' exit from entrepreneurship. Journal of Business Venturing, 3(1), 687-704. https://doi.org/10.1016/j.jbusvent.2016.09.002 
Bosma, N., Hessels, J., Schutjens, V., Praag, M.M., \& Verheul, I. (2011). Entrepreneurship and Role Models. Journal of Economic Psychology, 33(2), 410-424. https://doi.org/10.1016/j.joep.2011.03.004

Boudabbous, S. (2011). L'intention entrepreneuriale des jeunes diplômés. Revue Libanaise de Gestion et d'Economie, 4(6), 1-20. https://doi.org/10.1016/S1999-7620(11)70033-7

Bradley, S.W., Dean A.S., \& Wiklund, J. (2011). Swinging a Double-Edged Sword: The Effect of Slack on Entrepreneurial Management and Growth. Journal of Business Venturing, 26(5), 537-554. https://doi.org/10.1016/j.jbusvent.2010.03.002

Carmen, C.O., Juan, P.D.G., \& José, R.N. (2016). The influence of gender on entrepreneurial intention: The mediating role of perceptual factors. Business Research Quarterly, 19(4), 261-277.

Deci, E.L., Vallerand, R.J., Pelletier, L.G., \& Ryan, R.M. (1991). Motivation and education: the self-determination perspective. Educational Psychologist, 26(3-4), 325-346.

Dyer, W.G., Nenque, E., \& Hill, E.J. (2014). Toward a Theory of Family Capital and Entrepreneurship: Antecedents and Outcomes. Journal of Small Business Management, 52(2), 266-285.

Edelman, L., Tatiana, M., Galina, S., \& Tatyana, T. (2016). The impact of family support on young entrepreneurs' start-up activities. Journal of Business Venturing, 31(4), 428-448.

Engle, R., Dimitriadi, N., Gavidia, J., Schlaegel, Ch., Delanoë, G.S., Alvarado, I., He, X., Baume, S., \& Wolff, B. (2010). Entrepreneurial intent: A twelve country evaluation of Ajzen's model on planned behavior. International Journal of Entrepreneurial Behaviour and Research, 16(1), 37-57.

Eva, S.R. (2004). Pathways to successful entrepreneurship: Parenting, personality, entrepreneurial competence, and interests. Journal of Vocational Behavior, 65, 498-518. https://doi.org/10.1016/j.jvb.2003.10.007

Field, A. (2006), Discovering Statistics Using SPSS, 2nd ed., London: SAGE.

Figueiredo, C.R., \& Dias, F.V. (2012). Families: Influences in Children's Development and Behaviour, From Parents and Teachers' Point of View. Psychology Research, 2(12), 693-705.

Gibson, D.E. (2004). Role models in career development: New directions for theory and research. Journal of Vocational Behavior, 65(1), 134-156. https://doi.org/10.1016/S0001-8791(03)00051-4

. González, J., Kobylinska, U., Rodríguez, F., \& Nazarko, L. (2019). Antecedents of Entrepreneurial Intention among Young People: Model and Regional Evidence. Sustainability, 11, 69-93. https://doi.org/10.3390/su11246993

Gray, K.R.H., Foster, \& Howard, M. (2006). Motivations of Moroccans to be entrepreneurs. Journal of Developmental Entrepreneurship, 11(4), 297-318. https://doi.org/10.1142/S1084946706000507

Grolnick, W.S., Ryan, R.M., \& Deci, E. (1991). Inner resources for school achievement: Motivational mediators of children's perceptions of their parents. Journal of Educational Psychology, 83, 508-517.

Hair, J., Black, B., Babin, B., \& Anderson, R. (2010). Multivariate Data Analysis. 7th Edition. London: Prentice Hall.

Hair, J.F., Ringle, C.M., \& Sarstedt, M. (2011). PLS-SEM: Indeed a silver bullet. Journal Marketing Theory and Practice, 19, 139-152. https://doi.org/10.2753/MTP1069-6679190202

Hartsenko, J., \& Küttim, M. (2019). The Entrepreneurial Intentions of Students in Central and Eastern European Countries. Research in Economics and Business: Central and Eastern Europe, 11(2), 64-84.

Hayton, J.C., \& Cacciotti, G. (2014). Is there an entrepreneurial culture? A review of empirical research. Entrepreneurship and Regional Development, 25(9-10), 708-731. Retrieved from file://C:/Users/48605/Downloads/HaytonJ.C.CacciottiG.2013.IsthereanentrepreneurialcultureAreviewofempiricalresearch.EntrepreneurshipRegionalDevelopment259-10708-731.pdf on May 20, 2020.

Holienka, M., Milos, M., \& Marcin, P. (2013). Role of family entrepreneurial role models in determining students' preferences towards. Proceedings of ICERI, Conference 18th-20th November, Seville, Spain.

Howard, V.A., Fred, L., Fry, \& Stephens, P. (2006). The influence of role model on entrepreneurial intention. Journal of Developmental Entrepreneurship, 11(2), 157-167. https://doi.org/10.1142/S1084946706000349

Karimi, S.J.A., Biemans, H., Lans, T., Chizari, M., \& Mulder, M. (2014). Effects of role models and gender on students' entrepreneurial intentions. European Journal of Training and Development, 38(8), 694-727. https://doi.org/10.1108/EJTD-03-2013-0036

Kyriaki, F., Stijn, V.P., Bart, S., Maarten, V., \& Beiwen, Ch. (2014). Does Parental Autonomy Support Relate to Adolescent Autonomy? An In-Depth Examination of a Seemingly Simple Question. Journal of Adolescent Research, 29(3), 299-330. https://doi.org/10.1007/s11031-014-9450-1 
Leung, Y., Franken, H., \& Thurik, A. (2020). Psychiatric symptoms and entrepreneurial intention: The role of the behavioral activation system. Journal of Business Venturing Insights, 13, 1-10. https://doi.org/10.1016/j.jbvi.2019.e00153

Lima, E., Vânia, M., Jorge, N., \& Reed, E.N. (2014). Genre, classe sociale et entrepreneuriat : une attention particulière sur les étudiantes d'un pays émergent. 12ème Congrès International Francophone en Entrepreneuriat et PME 29, 30 et 31 Octobre, Agadir, Maroc.

Linan, F., \& Chen, Y.W (2009). Development and Cross-Cultural application of a specific instrument to measure entrepreneurial intention. Entrepreneurship Theory and Practice, 33(3), 593-617. https://doi.org/10.1111/j.1540-6520.2009.00318.x

Nahapiet, J., \& Ghoshal, S. (1998). Social capital, intellectual capital, and the organizational advantage. Academy of Management Review, 23(2), 242-266. https://doi.org/10.2307/259373

Netemeyer, R., Bearden, W., \& Sharma, S. (2003). Scaling procedures: Issues and applications. London: Sage Publications.

Prinzie, P., Stams, Geert. M., Dekovié, M., Reijntjes, A.H.A., \& Belsky, J. (2009). The relations between parents' Big Five personality factors and parenting: A meta-analytic review. Journal of Personality and Social Psychology, 97(2), 351-362. https://doi.org/10.1037/a0015823

Rodriguez, Tuggle, P.C.S., \& Hackett, S.M. (2009). An exploratory study of how potential family and household capital impacts new venture start-up rates. Family Business Review, 22(3), 259-272. https://doi.org/10.1177/0894486509341178

Shapero, A., \& Sokol, L. (1982). The social dimensions of entrepreneurship. Encyclopedia of Entrepreneurship, 72-90.

Sharma, L. (2014). Impact of family capital \& social capital on youth entrepreneurship - a study of Uttarakhand state, India. Journal of Global Entrepreneurship Research, 4(1), 1-18. https://doi.org/10.1186/s40497-014-0014-3

Sieger, P., Fueglistaller, U., \& Zellweger, T. (2011). Entrepreneurial Intention and Activities of Students across the World. International Report of the GUESSS Project 2011. St.Gallen: Swiss Research Institute of Small Business and Entrepreneurship at the University of St.Gallen (KMU-HSG).

Silk, J.S., Morris, A.S., Kanaya, T., \& Steinberg, L. (2003). Psychological control and autonomy granting: Opposite ends of a continuum or distinct constructs?. Journal of Research on Adolescence, 13, 113-128. https://doi.org/10.1111/1532-7795.1301004

Soenens, B., \& Vansteenkiste, M. (2005). Antecedents and outcomes of self-determination in three life domains: The role of parents' and teachers' autonomy support. Journal of Youth and Adolescence, 34, 589-604. https://doi.org/10.1007/s10964-005-8948-y

Soenens, B., Maarten V., Willy L.K., \& Goossens, L. (2007). Conceptualizing Parental Autonomy Support: Adolescent Perceptions of Promotion of Independence versus Promotion of Volitional Functioning. Developmental Psychology, 43(3), 633-46.

St-Jean, É., Nafa, A., Tremblay, M., Janssen, F., \& Baronet, J. (2014). Entrepreneurial intentions of university students: an international comparison between African, European and Canadian students. Entrepreneurship and Innovation Management, 18(2/3), 95-114. https://doi.org/10.1504/IJEIM.2014.062878

Wiani, A., Ahman, E., \& Machmud, A. (2018). Effect of family environment on interest in entrepreneurship students smk in subang regency. Jurnal Kajian Pendidikan Ekonomi dan Ilmu Ekonomi, 2(2), 2549-2284. 
Appendix A: Items constituting the measuring question instrument

\begin{tabular}{|c|c|}
\hline Constructs & Sources \\
\hline Entrepreneurial intention & \multirow{7}{*}{$\begin{array}{l}\text { Linan \& } \\
\text { Chen (2009) }\end{array}$} \\
\hline El1: I am ready to do anything to be an entrepreneur & \\
\hline EI2: My professional goal is to become an entrepreneur & \\
\hline EI3: I will make every effort to start and run my own firm & \\
\hline EI4: I am determined to create a firm in the future & \\
\hline EI5: I have very seriously thought of starting a firm & \\
\hline El6: I have the firm intention to start a firm some day & \\
\hline Parental support for autonomy as Promotion of independence & \multirow{20}{*}{$\begin{array}{l}\text { Silk et al. } \\
(2003), \\
\text { Grolnick et } \\
\text { al. (1991) } \\
\text { and Soenens } \\
\text { et al. (2007) }\end{array}$} \\
\hline My mother/father... & \\
\hline PI1: emphasizes that every family member should have some say in family decisions. & \\
\hline PI 2: emphasizes that it is important to get my ideas across even if others don't like it. & \\
\hline PI 3: says that you should always look at both sides of the issue. & \\
\hline PI 4: talks at home about things like politics or religion, taking a different side from others. & \\
\hline PI 5: pushes me to think independently. & \\
\hline PI 6: gives me more freedom to make my own decisions. & \\
\hline PI 7: admits that I know more about some things than adults do. & \\
\hline PI 8: often says I have to think about life myself. & \\
\hline PI 9: encourages me to be independent from him/her. & \\
\hline Parental support for autonomy as promotion of volitional functioning & \\
\hline PVF1: listens to my opinion or perspective when I've got a problem. & \\
\hline PVF2: lets me make my own plans for things I want to do. & \\
\hline PVF3: is usually willing to consider things from my point of view. & \\
\hline PVF4: isn't very sensitive to many of my needs. & \\
\hline PVF5: whenever possible, allows me to choose what to do. & \\
\hline PVF6: allows me to decide things for myself. & \\
\hline PVF7: insists upon doing things her/his way. & \\
\hline PVF8: allows me to choose my own direction in life. & \\
\hline Entrepreneurial role model & \multirow{9}{*}{$\begin{array}{l}\text { Howard } \\
\text { et al. } \\
(2006)\end{array}$} \\
\hline Do you have a self-employed parent or family member who you want to imitate and who: & \\
\hline ERM1: has significant discussions with you about their job or business. & \\
\hline ERM2: took you to work with them when you were 10 years old or younger. & \\
\hline ERM3: paid you to do minor tasks for them at work when you were $10-15$ years old. & \\
\hline ERM4: taught you significant details about managing a business or organization. & \\
\hline ERM5: discussed the advantages/disadvantages of joining the organization in which they work. & \\
\hline ERM6: included you in business discussions. & \\
\hline ERM7: encouraged you to take a career other than their organization where they work. & \\
\hline ERM8: encouraged you to know their colleagues. & \multirow{12}{*}{$\begin{array}{l}\text { Sieger et al. } \\
(2011) \text { and } \\
\text { Lima et al. } \\
(2014)\end{array}$} \\
\hline ERM9: encouraged you to read about their job or business. & \\
\hline ERM10: encouraged you to join their organization. & \\
\hline ERM11: took you to professional meetings. & \\
\hline $\begin{array}{l}\text { ERM12: encouraged you to join another organization for a few years and then join the organiza- } \\
\text { tion where they work. }\end{array}$ & \\
\hline Family support for entrepreneurship : & \\
\hline If I want to start a business & \\
\hline Financial capital & \\
\hline FC1: My family lends me money that I have to pay back (with interest). & \\
\hline $\begin{array}{l}\text { FC2: My family provides me with own capital (capital whose repayment without interest de- } \\
\text { pends on the success of my business). }\end{array}$ & \\
\hline $\begin{array}{l}\text { FC3: The capital provided by my family is accompanied by favorable and flexible conditions (e.g. } \\
\text { reduced interest rates or long repayment period). }\end{array}$ & \\
\hline Social capital & \\
\hline
\end{tabular}




\begin{tabular}{|l|}
\hline \multicolumn{1}{|c|}{ Constructs } \\
\hline $\begin{array}{l}\text { SC1: My family puts me in touch with people who could help me pursue my entrepreneurial ca- } \\
\text { reer. }\end{array}$ \\
\hline SC2: My family puts me in contact with business networks, partners and / or potential customers. \\
\hline SC3: My family offers me general knowledge about how to run a business. \\
\hline $\begin{array}{l}\text { SC4: My family provides me with industry-related knowledge about how to produce services and } \\
\text { products. }\end{array}$ \\
\hline SC5: My family coaches me / advises me in my entrepreneurial activities. \\
\hline $\begin{array}{l}\text { SC6: My family helps me by providing me with places or facilities for my } \\
\text { entrepreneurial activities. }\end{array}$ \\
\hline SC7: My family gives me access to a distribution network for my business. \\
\hline $\begin{array}{l}\text { SC8: Considering all the resources that my family provides me, I am completely independent of } \\
\text { them in the choice of the use of these resources. }\end{array}$ \\
\hline
\end{tabular}




\section{Authors}

Contribution share of authors is equal and amounted to $50 \%$ each of them. Syrine Kerkeni prepared the introduction and literature, while Nejib Ben Moussa reviewed material and methods, processed the statistical analysis, and prepared results, discussion, and conclusion.

\section{Nejib Ben Moussa}

Assistant Professor at the University of Jeddah, College of Business, Khulais Branch, Department of Human Resources Management, Kingdom of Saudi Arabia. Dr Ben Moussa earned his doctoral degree at the University Tunis el Manar, Science and Management Faculty of Tunis, Tunisia. His current research focuses on entrepreneurship, innovation, information systems, and human resources. He has published papers in Economics Bulletin, European Research on Management and Business Economics, etc.

Correspondence to: Dr Nejib Ben Moussa, Farhat Hached University Campus of El Manar - B.P. 248-El Manar II-2092 Tunisia, e-mail: nejibbenmoussa1503@gmail.com

ORCID ๑ http://orcid.org/0000-0001-7222-1601

\section{Syrine Kerkeni}

PhD student at the Faculty of Economic Sciences and Management of Tunis. Member of the GEMAS Laboratory at the FSEG Tunis.

Correspondence to: Syrine Kerkeni, Farhat Hached University Campus of El Manar - B.P. 248 - El Manar II 2092 Tunisia, e-mail: Syrine_kerkeni@outlook.fr

ORCID $\odot$ http://orcid.org/0000-0002-3988-8479

\section{Acknowledgements and Financial Disclosure}

We would like to thank the editors and reviewers for their constructive feedback on an earlier version of this paper.

\section{Conflict of Interest}

The authors declare that the research was conducted in the absence of any commercial or financial relationships that could be construed as a potential conflict of interest.

\section{Copyright and License}

This article is published under the terms of the Creative Commons

Attribution - NoDerivs (CC BY-ND 4.0) License

http://creativecommons.org/licenses/by-nd/4.0/ 
